\title{
Voting on slavery at the Constitutional Convention
}

\author{
Keith L. Dougherty · Jac C. Heckelman
}

Received: 17 September 2007 / Accepted: 29 February 2008 / Published online: 18 March 2008

(C) Springer Science+Business Media, LLC. 2008

\begin{abstract}
This paper provides the first empirical study of delegate voting behavior on issues of slavery at the U.S. Constitutional Convention. We analyze two categories of votes: those related to apportionment and those related to the regulation of the slave trade. Although it is widely believed that delegates voted consistent with the interests of their states on issues of slavery, we find that for votes on apportionment, the effect of state interests was enhanced by both the delegate's personal interest and his religious background. For votes regulating the slave trade, state interests had a significant effect but only within specific regions.
\end{abstract}

Keywords Slavery · Constitutional Convention · Ambition theory

\section{Introduction}

One of the paradoxes of the American founding was the rise of the principles of equality and liberty along with the institution of slavery. The Declaration of Independence proclaimed that "all men are created equal" and the Constitution secured the "blessings of liberty." Despite these lofty goals, delegates to the Constitutional Convention voted to include five clauses that promoted slavery: (1) seats in the House of Representatives and direct taxes were to be apportioned according to the free population and $3 / 5$ ths of slaves (Article I, Section 2); (2) Congress could not prohibit the importation of slaves until 1808 (Article I, Section 9); (3) taxes on imported slaves could not exceed ten dollars per slave (Article I, Section 9); (4) runaway slaves were to be returned to their masters "on demand" without

\section{K.L. Dougherty $(\bowtie)$}

Department of Political Science, University of Georgia, Athens, GA 30602, USA

e-mail: dougherk@uga.edu

\section{J.C. Heckelman}

Department of Economics, Wake Forest University, Winston-Salem, NC 27109, USA

e-mail: heckeljc@wfu.edu 
emancipation (Article IV, Section 2); and (5) the slave trade clause could not be amended until 1808 (Article V). ${ }^{1}$

The most widely accepted explanation for voting behavior on issues of slavery is that delegates acted according to the interests of their states (Rakove 1996: 71-5, 85-9). Yet, to date, no empirical study has been conducted on delegate motivations regarding slavery issues. $^{2}$ This is because delegates voted in state blocs. The Convention journal and Madison's notes recorded the vote of the state blocs, but they did not record the votes of the delegates individually.

We infer delegate positions on nine slavery votes at the Convention, then analyze various factors which could have affected their votes. ${ }^{3}$ Specifically, we use regression analysis to determine if delegates were influenced by their: (1) asset class (Beard [1913] 2004), (2) moral or ideological predispositions, (3) personal interest, and (4) state's interest.

Our results suggest that delegates were influenced by their state interests when voting on the overseas slave trade, but also by their personal and moral predispositions when voting on apportionment. The delegates' asset class, however, did not significantly influence their votes on either of these issues. The significance of certain personal interests suggests that delegates did not always rely exclusively on state interests when deciding how to vote on slavery issues.

Moreover, we also present an interesting finding for the votes on apportionment. The marginal effect from the number of slaves in a delegate's state was enhanced for delegates who ran for the U.S. House of Representatives. As apportionment would affect the number of seats available to each state in the House but not the Senate, our finding suggests delegates may have favored institutions that helped them advance their political careers.

The paper is divided into six sections. The next section briefly describes the history of slavery at the time of the founding and offers a short literature review. Section 3 describes the method of inferring delegate votes. Section 4 presents the empirical specifications and Sect. 5 discusses the results. Finally, the paper concludes by noting the significance of our research for the study of the Constitutional Convention.

\section{Historical context}

\subsection{Slavery in America}

The newly independent states of America attempted to address the issue of slavery prior to the Constitutional Convention. Between 1776 and the Constitutional Convention in 1787, ten of the thirteen states banned the importation of slaves from abroad. One of the three remaining states required "prohibitive" duties on slave imports while another had insufficient

\footnotetext{
${ }^{1}$ This list comes from Kaminski (1995). Finkelman (2001) adds Article 1, Section 9, Paragraph 4 which implies that any "capitation" or other "direct tax" would have to be apportioned according to the 3/5ths clause. See Finkelman (2001: 2-9) for additional clauses that were indirectly related to slavery.

${ }^{2}$ For an interesting discussion of the conflict between delegates who championed competent government and those who wanted to protect liberty see Holcombe (2002, chapters 3 and 4).

${ }^{3}$ There were 12 slavery votes at the Convention which break down as follows: six related to the apportionment of the legislature, two preventing Congress from prohibiting the importation of slaves, two related to taxes on slave imports, one related to runaway slaves, and one preventing the amendment of the slave trade clauses until 1808 (Kaminski 1995). This excludes motions to postpone or commit and clauses indirectly related to slavery.
} 
slaves to bother with the issue. ${ }^{4}$ Only Georgia failed to discourage their slave trade in any meaningful way. ${ }^{5}$ At the other extreme, Massachusetts abolished slavery outright and Pennsylvania and Connecticut passed legislation for the gradual emancipation of their slaves.

The general mood was to leave the question of slavery to the states. ${ }^{6}$ The First Continental Congress agreed to a boycott of British shipping and to a prohibition of slave imports. This agreement was an attempt to attain concessions from the British which many viewed as temporary. When the war ended, the slave trade re-emerged (Kaminski 1995: 16). Quakers petitioned Congress to end the slave trade and Methodists petitioned the Virginia legislature to abolish slavery outright (Miller 1991: 21-22). Neither group made much progress. Congress implicitly left the decision to the states and the Virginia legislature repealed its manumission act (Kaminski 1995: 33).

\subsection{Motivation of the framers}

Scholars typically describe the debate over slavery at the Convention as a conflict between "anti-slavery representatives" and "slave state representatives" (Maltz 1992). Most of their focus has been on philosophical or legal principles produced by the document (Allen 1988; Freehling 1972; Ohline 1971) and on carefully describing the debate along with the state interests on each vote (DuBois [1896] 1969; Robinson 1971; Kaminski 1995; Rakove 1996; Finkelman 2001). To better understand the literature on delegate motivations, one must look more broadly.

Perhaps the most seminal work on the motivation of the framers was Beard's ([1913] 2004) "economic interpretation." Beard argued that delegates could be bundled into two asset classes: those with real-estate interests (realty) and those with securities interests (personalty). Beard claimed that "the movement for the Constitution of the United States was originated and carried through principally by four groups of personalty interests which had been adversely affected under the Articles of Confederation" (Beard [1913] 2004: 324). Because these interests were economically based, Beard believed the framers were frequently at odds with their own constituents (Barrow 2000).

Beard's view dominated historical interpretations of the Constitution until the midtwentieth century, when historians wrote detailed critiques of the Beard thesis (Brown 1956; McDonald 1958). As part of his study, McDonald (1958) inferred the voting patterns of delegates for sixteen separate Convention votes (none of which were related to slavery). Without presenting any statistical analyses, he concluded that "the facts did not substantiate [Beard's] assumptions" (McDonald 1958: 400).

Jillson and Anderson (1977) and Jillson (1981) were among the first scholars to study the Constitutional Convention using statistical analysis. However, their studies were limited to

\footnotetext{
${ }^{4}$ States that banned the importation of slaves were Massachusetts (which abolished slavery outright by judicial interpretation of the Constitution of 1780), Connecticut (1774), Delaware (1776), Pennsylvania (1780), Maryland (1783), New York (1785), New Jersey (1786), Rhode Island (1787), and Virginia (1778), and South Carolina (1787) for three years. For a summary of these laws see DuBois ([1896] 1969: 223-229). New Hampshire did not formally abolish slavery because there were so few slaves (157 in total according to 1790 Census records) that it was not worth public notice (Ibid.: 30). By the time of the Convention, North Carolina had enacted what the state assembly called a "prohibitive duty" (Ibid.: 229).

${ }^{5}$ Georgia's taxation on imported slaves coincided with its taxes on other imports. See for example the acts passed September 29, 1773 and July 26, 1783 (Candler 1968: vol. 19, I, 439; vol. 19, II, 237).

${ }^{6}$ The only national document that took a permanent stance on slavery between the Declaration of Independence and the end of the Constitutional Convention was the Northwest Ordinance of 1787. The act declared that states admitted to the union northwest of the Ohio River would be on equal footing with the original thirteen states and that slavery would be prohibited in the new territory.
} 
the votes of state blocs, which prevented them from examining any disagreements between delegates from the same state and forced them to exclusively use state variables.

The first quantitative studies to return to the question of what motivated the delegates individually were conducted by McGuire and Ohsfeldt $(1984,1986)$ and McGuire $(1988$, 2003). McGuire and Ohsfeldt used the data originally gathered by McDonald (1958) and added inferences for delegates not in attendance. By applying econometric methods to this expanded set of delegates on the same sixteen votes, they were able to systematically investigate whether delegates acted upon their personal economic interests when constituent interests and delegate ideology were controlled. They concluded that both personal economic interests and constituent interests affected delegate voting behavior at the margin.

Heckelman and Dougherty (2007) presented a detailed critique of the inferences made by McDonald (1958) and McGuire and Ohsfeldt (1986, 1997), re-inferred the same 16 votes using primary source data, and concluded that personal interests were more important than constituent interests. Although these more recent studies represent the most advanced empirical work on the motivation of the delegates at the Constitutional Convention, they do not include any issues related to slavery.

\section{Recovering delegate votes and preferences on slave clauses}

All that is known about delegate votes with certainty is that the majority vote of each delegation determined the vote of the state. In order to empirically investigate delegate voting behavior, the votes of the individual delegates will have to be inferred.

Using the process described in this section, we were able to infer positions for many of the delegates on nine separate votes related to slavery. As detailed in Table 1, six votes relate to the inclusion of slaves in the apportionment of the legislature (vote 39 to vote 253), two relate to preventing the prohibition of the slave trade until 1808 (vote 367 and vote 368 ), and one relates to a tax on the importation of slaves (vote 999). ${ }^{7}$ Unfortunately, delegate positions on the fugitive slave clause and the clause prohibiting amendments on slave imports (items 4 and 5 in the introduction) could not be assessed. Both passed without debate and delegates wrote very little about their personal views on these issues. Finally, we had insufficient information to infer delegate positions on an additional vote limiting taxes on imported slaves, which was similar to vote $999 .{ }^{8}$ Thus, we were able to analyze nine of the twelve Convention votes related to slavery.

To infer delegate level votes, we follow McDonald's (1958) original design and assume delegates voted in a manner consistent with their statements in speeches and written correspondences. In this way, we can equate their stated positions with their actual voting behavior. Two observations support this assumption. First, since votes were taken verbally and sequentially, delegates who stated positions contrary to their vote could incur fairly high costs. Other delegates would notice their inconsistencies and might discount their statements on

\footnotetext{
${ }^{7}$ We assigned this vote number 999 as a placeholder since it was unnumbered (Farrand 1966: vol. 2, 417, August 25).

${ }^{8}$ This vote changed the language of vote 999 by substituting that a tax on imported slaves shall not exceed "the common impost on articles not enumerated" with "ten dollars for each person." The proposal passed by the unanimous agreement of the states. Vote 999 then represented an up or down vote on the amended proposal itself. We could not infer delegate positions on the first vote because we could not accurately infer whether delegates believed the common impost on non-enumerated articles was greater than, or less than, ten dollars.
} 
Table 1 Slavery votes at the Constitutional Convention

Vote \# Description of Issue

39 To change the right of suffrage in the first branch from ought to be "some equitable ratio of representation ... [not] established in the Articles of Confederation" to "in proportion to the whole number of white and other free citizens and inhabitants of every age, sex and condition, including those bound to servitude for a term of years and three fifths of all other persons not comprehended in the foregoing description, except Indians not paying taxes, in each State." Since the status quo is "some equitable ratio" a yea vote is considered pro-slavery ( 9 yea, 2 nay).

132 To strike out the words three-fifths as in the principle of apportioning representatives, as proposed by the committee of five and replace it with Blacks as equal to Whites (3 yea, 7 nay).

136 To adopt $3 / 5$ of the Blacks in the apportionment of representatives. Since this is a vote to accept the clause first laid out in vote 39 , the status quo would be to apportion representatives equally among states, as under the Articles of Confederation. A yea vote is considered pro-slavery (4 yea, 6 nay).

145 To rate Blacks as equal to Whites, instead of as $3 / 5$, in the apportionment of Representatives. This was Pinckney's substitute to Randolph's motion of $3 / 5$ ths. A yea vote is considered pro-slavery (2 yea, 8 nay).

147 To proportion representatives and direct taxes on the number of Whites and $3 / 5$ of the Black inhabitants; and to require a Census in six years-and every ten years afterwards. Since this was a vote to accept the more complete provision, the status quo was apportioning representatives equally among states and taxing according to land values, as under the Articles of Confederation. A yea vote is considered pro-slavery (6 yea, 2 nay, 2 divided).

253 To insert "free" before "inhabitants" in the clause: "the legislature shall ... regulate the number of representatives by the number of inhabitants, according to the provisions herein after made, at the rate of one for every forty thousand." Because the proposal contradicts the $3 / 5$ ths clause previously adopted, a nay vote is considered pro-slavery (1 yea, 10 nay).

367 To strike out 1800 as the year limiting the importation of slaves in the proposal from the committee of eleven and to insert 1808. Because this amendment allows less restriction on the importation of slaves, a yea vote is considered pro-slavery ( 7 yea, 4 nay).

368 To accept the clause: "The migration or importation of such persons as the several States now existing shall think proper to admit, shall not be prohibited by the Legislature to the year 1808." Because this is a vote to accept the provision, the status quo would be no limitation, as under the Articles of Confederation. A yea vote is considered pro-slavery (7 yea, 4 nay).

$999^{\dagger} \quad$ To accept a duty on the importation of slaves shall not exceed ten dollars for each person. Since this was a vote to accept the provision, the status quo in this case would be no tax on the importation of slaves as under the Articles of Confederation. However, delegates compared this clause to the version from the Committee of Detail (Art. 7, sec. 5) which explicitly forbade federal taxes on the importation of slaves. Because we coded it based on these statements, a nay vote is considered pro-slavery.

Notes: Vote numbers correspond to those appearing in Farrand (1966). State votes, appearing in parentheses, correspond to Madison's notes

$\dagger$ Vote 999 is unnumbered (August 25, Ibid., vol. 2, 417). Since neither Madison nor the journal recorded state votes on this question, we made no assumption about state votes here

future votes. Second, in cases where historians believe there was a vote trade (such as passage of votes 367 and 368 traded for rejection of a 2/3rds majority to pass navigation acts) delegates who were allegedly parties to the vote trade always stated positions consistent with the vote trade they were about to cast or they remained silent. Thus, there is good reason to expect strategic "talking" to be rare.

Our inference of delegate level votes proceeded in three basic steps, similar to the steps outlined by Heckelman and Dougherty (2007). We implement a fourth step in the Appendix to obtain additional observations used in supplemental regressions. 
In the first step, we compared state level votes with attendance records. By the rules of the Convention, the position of each state (yea, nay, divided) was determined by a simple majority of the state's delegates (Jillson 1988). In addition, a state was recorded as absent in Madison's notes or in the journal if it did not have enough delegates on the floor to maintain the minimum required by its credentials (Farrand 1966: vol. 3, 559-86). ${ }^{9}$ Because a state's position was determined by majority rule, we could automatically code a delegate's vote the same as his state's vote if there were only two delegates in attendance from a state and the state vote was yea or nay. For example, on vote 368 to prevent the national government from prohibiting the importation of slaves until 1808 (see Table 1), we were able to code William Samuel Johnson and Roger Sherman from Connecticut as voting yea, because the only other delegate from Connecticut, Oliver Ellsworth, was absent and the state voted yea.

In the second step, we inferred additional votes using delegate statements in debate (Farrand 1966), their manuscripts (Hutson 1987; Kaminski and Saladino 1995), and other sources. ${ }^{10}$ Delegate votes were inferred from explicit statements in these documents. For example, we coded Charles Cotesworth Pinckney, a delegate from South Carolina, as voting yea on 368 because he motioned the ultimate wording of 368 and spoke in favor of the idea on more than one occasion (Kaminski 1995: 60-61; Farrand 1966: vol. 2, 415). Likewise, we coded Charles Pinckney, also from South Carolina, as voting yea on vote 368 because Madison recorded Pinckney as saying he would consider a rejection of the clause protecting the importation of slaves until 1808 "as an exclusion of South Carolina from the union" (Farrand 1966: vol. 2, 371-2). The vote of George Mason, a delegate from Virginia, was coded as a nay because Mason explicitly listed this clause as one of the reasons he opposed the Constitution (Kaminski and Saladino 1995: vol. 14, 151). We continued this process for all remaining delegates with stated positions.

In our third step, we inferred additional votes by comparing the previously inferred votes against the vote recorded for each state. For example, two of the delegates from Massachusetts (Nathaniel Gorham and Rufus King) had been coded yea on vote 368 and a third delegate (Elbridge Gerry) was coded as nay on vote 368, based on their stated positions. Because the recorded state vote was yea, the lone remaining delegate (Caleb Strong) must have voted yea to ensure that a majority of the Massachusetts delegates voted yea, in accordance with their state vote. All inferences based on these three steps are presented in Table 2. A yea vote can be considered pro-slavery for all nine of the votes, except vote 253 and vote 999 where nays are treated as pro-slavery. ${ }^{11}$

As it turns out, the code for each delegate on 368 is identical to his code for 367 , so only one of the votes will be used in the regression analysis to avoid redundancy. ${ }^{12}$ To make this

\footnotetext{
${ }^{9}$ This minimum ranged from one delegate for Connecticut to four for Pennsylvania. The number required for New York and Maryland were not clearly specified, but in practice the Convention treated New York's minimum as three.

${ }^{10}$ Of the 55 delegates attending the Convention, 26 have published manuscripts and 34 have published biographies. These sources, and the congressional record for the case of $3 / 5$ ths compromise (April 1783), were also used.

${ }^{11}$ We determined whether a yea or a nay vote was pro-slavery by comparing the proposal to the status quo. For example, a yea on vote 132 is considered pro-slavery because the proposal is to replace $3 / 5$ ths Blacks with $5 / 5$ ths Blacks in the apportionment. A yea on vote 136 is also considered pro-slavery because the motion is run against the status quo of no agreement on apportionment, which does not include Blacks (or any population). Most delegates viewed vote 999 in contrast to the report from the Committee of Detail which exempted slaves from import duties (Farrand 1966). As such, vote 999 would allow for taxation on slaves that would not otherwise exist. Thus, a nay vote on this clause is considered pro-slavery.

${ }^{12}$ Vote 367 and vote 368 are basically the same. The first replaces "1800" with " 1808 " in the clause that prevents Congress from banning the importation of slaves until the specified date. The second accepts the
} 


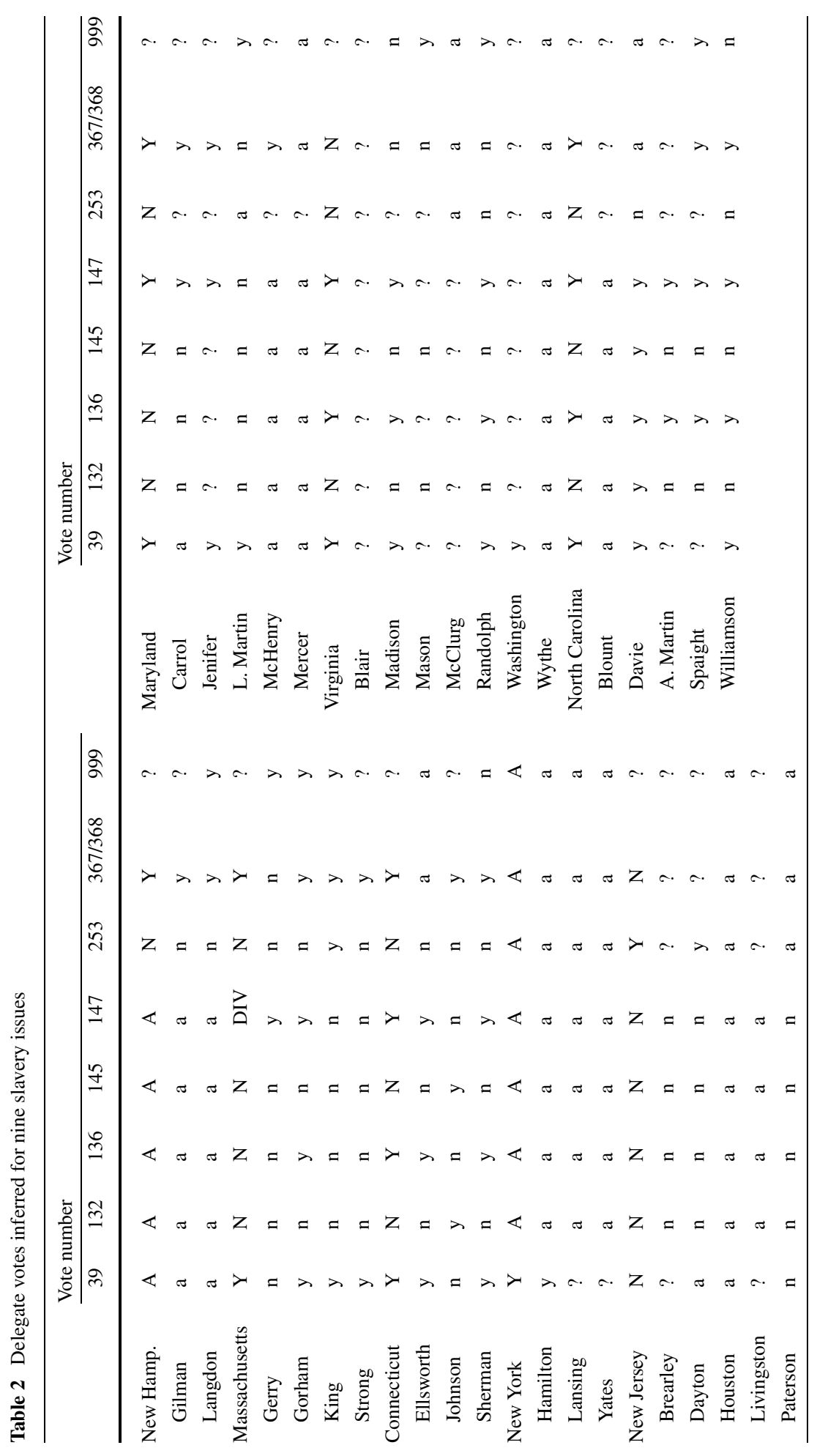




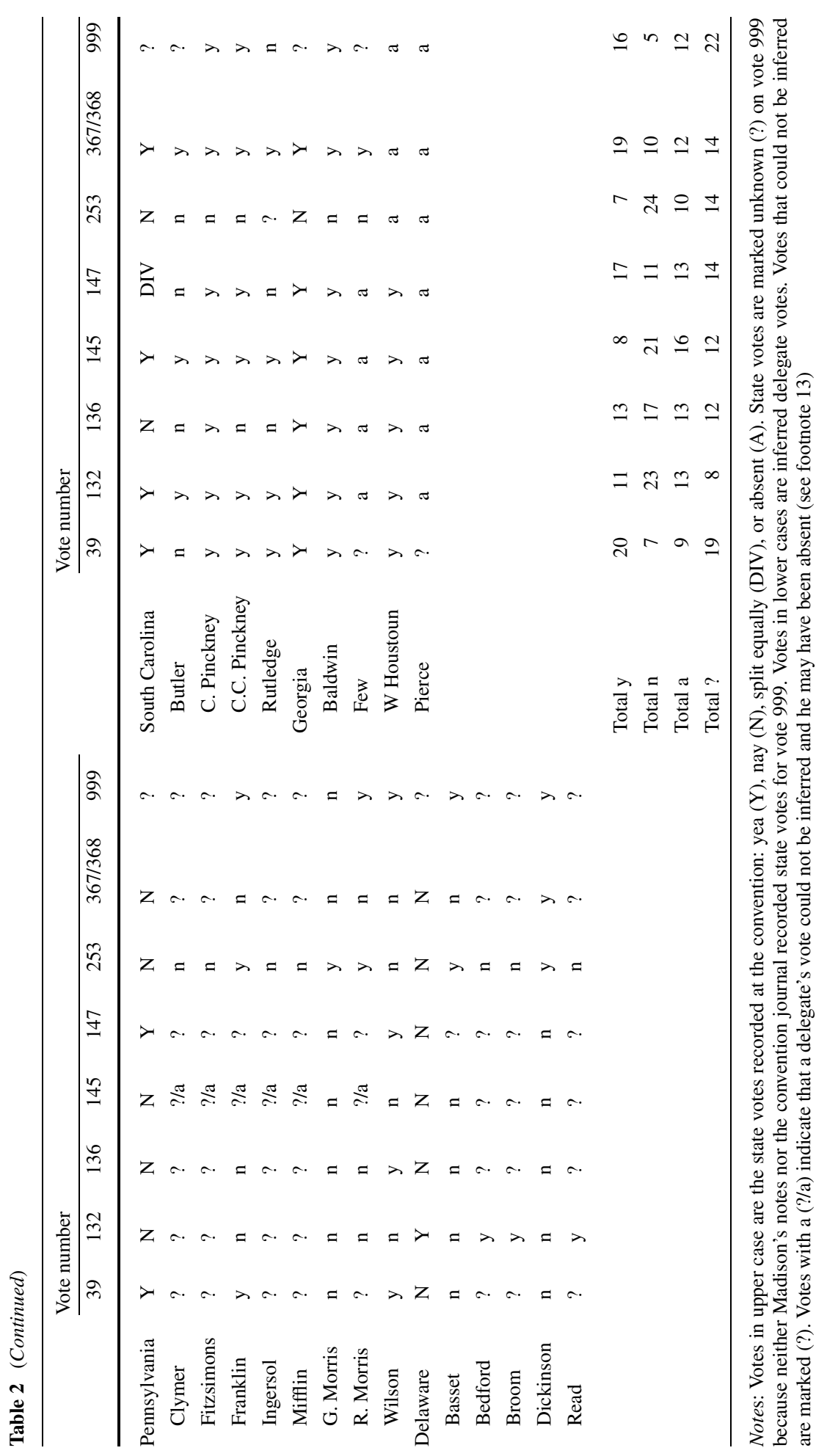


clear, these votes are presented only once in the table and identified as $367 / 368$. For each motion, we are able to infer anywhere between $49 \%$ and $81 \%$ of the votes for the delegates in attendance. In the worst case scenario, vote 999 , we were able to recover only 21 positions. ${ }^{13}$ In total, we were able to infer 179 of the 260 potential observations on the apportionment votes and 79 of the 129 potential observations on the slave regulation votes-roughly $2 / 3$ of all recoverable votes. ${ }^{14}$

Some preliminary observations are worth noting. First, the proportion of uncoded inferences in a state varied with the size of the delegation. The two largest state delegations (Pennsylvania and Virginia) are the only states missing more than half of the potential yea/nay votes. Second, as might be expected, the proportion of delegates in agreement from a state is negatively correlated with the number of delegates from a state in attendance $(\rho=-0.502)$, signifying that smaller delegations were more likely to agree than larger delegations. Third, southern delegates (representing states from Delaware, southward) were $48 \%$ more likely to vote pro-slavery than northern delegates. The difference in proportions is significant at the 0.01 level. Still, as is clear from a cursory view of Table 2, not all southern (or northern) delegates agreed with each other on these issues.

\section{Empirical specifications}

We group the nine votes described in Table 1 into two categories: those related to apportionment (votes 39-253) and those related to the regulation of slave imports (votes 367-999). We pool the votes within each category. We then create two specifications, one for each category, to properly capture the different economic interests related to each set of votes. In our regression framework, the dependent variable $(v)$ for both groups of votes is a dummy variable coded 1 if the delegate's vote is pro-slavery; 0 otherwise.

\subsection{Apportionment clauses}

Our empirical specification for the apportionment votes takes the form

$$
\begin{aligned}
v= & \alpha_{0}+\alpha_{1} \text { personalty }+\alpha_{2} \text { religion }+\alpha_{3} \text { slaves per capita } \\
& +\alpha_{4}(\text { slaves per capita } \times \text { House })+e
\end{aligned}
$$

where the $\alpha$ 's are parameters to be estimated, and $e$ is a random error term.

In our specification, personalty is a dummy variable for whether the delegate was from the personalty class. We coded personalty using Beard's own list ([1913] 2004: 150-151). This includes delegates who invested in money, securities, speculative lands, manufacturing and shipping, or slaves. Beard argued that these coalitions prevailed throughout the Convention. We include the variable here because the votes on slavery were a subset of all the votes

\footnotetext{
clause as stated. Perhaps not surprisingly, the inferred positions for the delegates are identical across the two votes. For the purposes of pooling, we include only one of these votes to avoid over-sampling the issue.

${ }^{13}$ State votes are not recorded for vote 999 and thus we can not rely on majority rule to infer individual delegate votes in steps 1 and 3. In addition, contrary to his standard practice, Madison specifies that Pennsylvania voted nay on vote 145 by three to two. This implies that three delegates were absent but attendance records make no indication of who they were. Hence, we code only the two Pennsylvanian delegates who spoke that day.

${ }^{14}$ As stated earlier, we also generate additional observations using spatial modeling techniques. These procedures, and regressions based on this larger sample, are discussed in the Appendix.
} 
considered. We do not form an expectation regarding the sign of $\alpha_{1}$ because Beard does not specify how the groups would vote on apportionment. He only claims members of the same group tended to vote together.

In addition, delegates may have been influenced by their ideological or moral predispositions (Jensen 1964; Diamond 1981). Predisposition is unobservable and inherently difficult to measure. ${ }^{15}$ For issues of slavery, some religions provide a reasonably good measure of moral predisposition toward the treatment of slaves. At the time of the Constitutional Convention, Quakers, Methodists, Shakers, and some other religions actively opposed the slave trade. Because Quakers and Methodists were the only active "anti-slavery" religions represented at the Convention, the dummy variable religion is coded as a one if a delegate was a Quaker or a Methodist, and zero otherwise. ${ }^{16}$ We hypothesize that $\alpha_{2}<0$.

Our third independent variable, slaves per capita, is defined as the slaves per capita in a delegate's state, taken from the 1790 census. This variable measures the advantage to a state from including Blacks in the apportionment. Although most of the apportionment votes referred to Blacks, not slaves, including slaves in the apportionment was clearly the goal of those who proposed such clauses. Furthermore, slaves per capita correlates with the per capita number of slaves and other peoples (which includes free Blacks, mulattoes, and Native Americans) at 0.99 . Hence, the difference between Blacks and slaves is virtually irrelevant for our analysis. ${ }^{17}$ States with more slaves per capita would gain additional seats in the legislature at the expense of states with fewer slaves. ${ }^{18}$

The apportionment of the House of Representatives could also affect the delegates directly if they intended to run for the House, because changing the number of seats allocated to a state could affect their chances of being elected to that chamber. Consistent with ambition theory (Schlesinger 1966; Kernell 1977; Jacobson and Kernell 1983), an ambitious delegate who wanted to run for the House might be more inclined to vote for an apportionment that improved his chance of winning a seat. The dummy variable House is thus included to indicate if the delegate subsequently ran for the House of Representatives in either of the first two federal elections. ${ }^{19}$ This variable proxies for the delegate's personal interest in the vote. We hypothesize that delegates who ran for the House were more likely to favor the inclusion of Blacks in the apportionment proportional to the number of slaves

\footnotetext{
${ }^{15}$ McGuire (2003) measures ideology using variables such as age and English ancestry.

${ }^{16}$ Bradford (1982) lists Congregationalists, Diests, Dutch Reformed, Episcopalians, Lutherans, Presbyterians, and Roman Catholics as the other denominations represented at the Convention. We thank Marie Bradford for helping us track down this source.

${ }^{17}$ The few scattered records of free Blacks indicate that they were a small percentage of the population. For example, free Blacks were less then $2.0 \%$ of the population of Rhode Island in 1783 and less than $0.3 \%$ of the population of New Hampshire in 1786 (United States 1975: vol. 2, 1170).

${ }^{18}$ We used slaves per capita rather than Blacks per capita because the Census Bureau does not report free Blacks (or Blacks) as a separate category. Further note that the 1790 census enumerates three distinct areas which were not yet independent states. Kentucky was a district of Virginia until 1791. Hence, we added Kentucky data to the data for Virginia. Maine was officially a district of Massachusetts until 1820. Hence, we added the data for Maine to the data for Massachusetts. Finally, the area of Vermont was claimed by both New Hampshire and New York. Since delegates from these states would not know the future division of Vermont, we did not include Vermont in either of the state totals.

${ }^{19}$ The coding of House is taken from Dubin (1998) with support from Garraty and Carnes (1999). The only delegate who ran for the U.S. House of Representatives that is not listed in Dubin (1998) is William Pierce. We code Pierce as running for the House because we wanted to be consistent with Garraty and Carnes (1999) and because Dubin omitted candidates who received an extremely small number of votes. Changing the code for Pierce does not affect the results.
} 
in their state. ${ }^{20}$ While some delegates may have sought other political offices, the apportionment of the House would only affect the number of opportunities available to those running for the House.

The interaction term appearing in (1) determines whether the slaves in a delegate's state had a greater impact for delegates who ran for U.S. House of Representatives than delegates who did not. The overall marginal effect for these delegates is represented by $\alpha_{3}+\alpha_{4}$ House. Because House is a dummy variable, the parameter $\alpha_{3}$ by itself represents the marginal effect from additional slaves in the delegate's state given the delegate does not run for the House and $\alpha_{3}+\alpha_{4}$ represents the marginal effect from additional slaves given that the delegate did run for the House. Thus we expect $\alpha_{3}+\alpha_{4}>\alpha_{3}>0$ which indicates that running for the House provides an additional effect that is greater than the effect captured by the number of slaves per capita in a delegate's state by itself. ${ }^{21}$

\subsection{Regulation of slave imports}

The remaining votes in our sample treat slaves as commodities. The regression specification for these votes is

$$
\begin{aligned}
v= & \beta_{0}+\beta_{1} \text { personalty }+\beta_{2} \text { religion }+\beta_{3} \text { slaveowner } \\
& +\beta_{4}(\text { slaves per capita } \times \text { Lower South })+\beta_{5}(\text { slaves per capita } \times \text { Upper South }) \\
& +\beta_{6}(\text { slaves per capita } \times \text { North })+e .
\end{aligned}
$$

As before, class interests and moral predispositions are measured by personalty and religion, respectively. Again, we do not predict a specific sign for $\beta_{1}$ and we expect $\beta_{2}<0$.

However, the delegate's personal interest is now measured by slaveowner, which equals one if the delegate owned slaves and zero otherwise. ${ }^{22}$ Restricting imports would decrease the total supply of slaves and increase the price for foreign slaves. This in turn would increase demand for domestic slaves and increase domestic slave prices. We believe delegates who already owned slaves were more likely to purchase additional slaves than delegates who did not own slaves. Because only one delegate professionally sold slaves (Jenifer from Maryland), ${ }^{23}$ slaveowner should indicate a stronger interest in an open slave market; thus we expect $\beta_{3}>0$.

Regulation of the slave trade also affected the interests of a delegate's state. As before, state interests are still measured by the number of slaves per capita in the state but in this

\footnotetext{
${ }^{20}$ There is a possibility that the decision to run for the House was endogenous to the apportionment rule adopted.

${ }^{21}$ Because there is no separate independent effect from running for a House seat we do not include House as an additional separate independent variable in our regressions. In alternative regressions (not reported) House was never found to be statistically significant when added separately to the specification in (1).

${ }^{22}$ We thank Robert McGuire for the use of his data on slave ownership. We also considered replacing slaveowner with a variable measuring the number of slaves owned by each delegate, but found substantial discrepancies across sources in the number of slaves owned by each delegate. For example, William Blount owned 30 slaves according to McDonald (1958), 80 slaves according to McGuire, and 52 slaves according to the 1790 census ( 30 slaves in his Pitt county estate and 22 slaves in his Tyrell county estate).

${ }^{23}$ This statement is based on Garraty and Carnes (1999) as well as a dozen biographies of various delegates. To address the possibility that Jenifer's interests favored the regulation of slave imports, we re-coded the slave owner variable $-1,0,1$ representing slave supplier (uniquely Jenifer), non-slave owner, and slave demander. This did not affect the results, nor did dropping Jenifer from the sample.
} 
case slaves per capita is used as a proxy for the value of the slave trade among constituents. Restricting imports decreases the total supply of slaves and increases the price of both foreign and domestic slaves. States which were net importers of slaves would be hurt by such a practice while states which were net exporters of slaves to other states would benefit. The net importing states were in the Lower South (North Carolina, South Carolina, ${ }^{24}$ Georgia) and the net exporting states were in the Upper South (Delaware, Maryland, and Virginia). Hence, the Upper South and Lower South may have had opposite interests in votes to regulate the slave trade. More slaves in a state from the Lower South might correspond to stronger sentiment for the free importation of slaves while more slaves in a state from the Upper South might correspond to stronger sentiment for the regulation of slave imports. The separate interactions of the regional dummy variables and slaves per capita in (2) allow each region to have its own conditional interests based on the slaves per capita in a delegate's home state. The coefficient on the interaction terms then represent the impact of intra-regional differences in slaves per capita on the dependent variable. For these reasons, we hypothesize that $\beta_{4}>0$ and $\beta_{5}<0$.

A regional interaction for the remaining states of the North is included for completion. ${ }^{25}$ Northern states had far fewer slaves per capita than the rest of the nation (an average of 0.01 compared to 0.28 for the Upper South and 0.34 for the Lower South). As such they would not be directly affected by ending the slave trade. Even though there was variation in the number of slaves in each of the northern states, the total number was small. With so few slaves in their states, it is unlikely that any of the northern delegates would have viewed their state's interest on regulating the slave trade much differently than another delegate from the North. If any economic incentive exists for the northern states it should be slight.

Traditionally, the slave interests of Maryland and Virginia have been treated separately from the rest of the South and the North (DuBois [1896] 1969; Farrand 1966: vol. 2, 370373; Finkelman 2001). For our purposes, it is not quite clear whether Delaware should be considered part of the Upper South or North. Geographically, Delaware borders both regions. It also has twice as many slaves per capita as New Jersey (the next highest northern state) and half as many slaves per capita as Maryland (the next lowest state from the Upper South).

We initially classify Delaware as part of the Upper South to reduce the possibility of a spurious correlation from using only two states as the Upper South and to increase the variation of slaves per capita across delegates from this region. ${ }^{26}$ We also considered Delaware

\footnotetext{
${ }^{24}$ Even though South Carolina banned the importation of slaves in 1787 , this ban was only for three years (Kaminski 1995: 168, n. 11). It was mostly an attempt to alter the ratio between slaves and whites in order to avoid slave revolts. It was not a sign that South Carolina had some latent predilection against the slave trade.

${ }^{25}$ Specification (2) is equivalent to $v=\delta_{0}+\delta_{1}$ personalty $+\delta_{2}$ religion $+\delta_{3}$ slaveowner + $\delta_{4}$ (slaves per capita $\times$ Lower South $)+\delta_{5}$ (slaves per capita $\times$ Upper South $)+\delta_{6}$ slaves per capita $+e$. In such a formulation, the coefficient on slaves per capita alone would still capture the effect in the North because the North would represent the default region. However, the coefficients on the regional interactions for Upper South and Lower South would represent the marginal impact of slaves per capita in that region relative to the default North. Hence, $\delta_{4}+\delta_{6}$ would represent the total marginal impact of slaves per capita in the Lower South and $\delta_{5}+\delta_{6}$ would represent the total marginal impact of slaves per capita in the Upper South. We use specification (2) because it is easier to interpret.

${ }^{26}$ Our classification scheme is supported by the fact that Delaware did not abolish slavery until passage of the 13th Amendment in 1865, which Delaware did not ratify until 1901. The last northern state to abolish slavery was New Jersey in 1804. More importantly, Delaware's 1787 and 1789 bans on the export of slaves to other states applied only to those "without a license or permit" (Delaware 1797: 884-5, 942-3). In other words, Delaware seems to have purposefully left loopholes in its legislation to help protect its slave exporters. Still, Delaware officially prohibited the importation of slaves in 1776 and had a greater rate of manumission than
} 
as part of the North in a separate, unreported regression. It turns out, however, that the classification of Delaware does not affect our results. The sign and significance of all the variables remain the same in both regressions.

\subsection{Other estimation issues}

Since the true vote of each delegate is unknown, our inferred votes, $v$, are estimated as $v=v^{*}+u$, where $v^{*}$ is the latent true vote and $u$ is the error in our inference. There is no reason to expect $u$ to be correlated with any of our independent variables and thus our regression error $z=u+e$ suggests some degree of heteroskedasticity but not biased coefficient estimates. Because the exact form of heteroskedasticity cannot be derived, we estimate the equations using robust standard errors. Although we present results using probit estimation, logit produces similar results.

Because we are pooling votes, we also include dummy variables for the individual votes. The values for the independent variables for each vote do not vary within a specification except by the sample of delegates included, yet the mean value of the dependent variable varies substantially (see the comparisons at the bottom of Table 3). The dummy variables represent intercept shifts which capture the underlying tendency for delegates to vote a certain way on any given vote. The estimated coefficients then represent marginal effects from this baseline tendency.

\section{Results}

\subsection{Apportionment clauses}

Coefficient estimates for the pooled apportionment votes are presented in Table 3, with absolute $t$-statistics generated from robust standard errors underneath. In the first column, representing specification (1), each of the estimated coefficients has the hypothesized sign and is statistically significant, with the exception of personalty for which we had no hypothesis regarding its sign. The estimated coefficient for personalty indicates those of the personalty class were somewhat more likely than those of the realty class to support including Blacks for the purposes of apportionment, but the difference is not statistically significant at conventional levels.

Delegates from religions actively opposed to the slave trade were significantly less likely to support including Blacks in the apportionment relative to delegates from other religions. This is consistent with the notion that delegates with a moral predisposition against slavery would want slaves excluded from the apportionment, because including them would give "encouragement to the slave trade" (Gouveneur Morris, Farrand 1966: vol. 1, 588).

Delegates from states with larger slaves per capita were significantly more likely to support the inclusion of Blacks in the apportionment. In addition, the estimated coefficient on the interaction term (slaves per capita $\times$ House) reveals that this effect was even greater for delegates who ran for the U.S. House of Representatives than for their co-state delegates who did not run. Both would have the same value for slaves per capita and as anticipated $\alpha_{3}+\alpha_{4}>\alpha_{3}>0$. In other words, delegates who could personally gain from the apportionment votes were more likely to vote consistent with their personal interests.

New York or New Jersey between 1775 and 1810 (Essah 1996: 38; Williams 1996: 145). Hence, Delaware could be classified as part of either the Upper South or the North. 
Thus we conclude that, at the margin, delegates responded to their moral predisposition (religion), their personal ambition (slaves per capita $\times$ House), and their state's interest (slaves per capita). We are less confident that the delegates' economic class (personalty) was a relevant factor.

Table 3 Determinants of Votes on Slavery Issues

\begin{tabular}{|c|c|c|c|c|}
\hline & \multicolumn{2}{|c|}{ Apportionment votes } & \multicolumn{2}{|c|}{ Regulation votes } \\
\hline & (I) & (II) & (III) & (IV) \\
\hline \multirow{2}{*}{ constant } & -0.09 & 0.13 & 1.34 & \\
\hline & 0.22 & 0.32 & 0.99 & \\
\hline \multirow[t]{2}{*}{ personalty } & 0.43 & 0.20 & -0.95 & -0.94 \\
\hline & 1.29 & 0.66 & 0.75 & -0.74 \\
\hline \multirow[t]{2}{*}{ religion } & $-1.34^{* *}$ & $-1.32^{* *}$ & -0.54 & -0.59 \\
\hline & 3.18 & 3.12 & 0.77 & 0.67 \\
\hline \multirow[t]{2}{*}{ slave owner } & & & -0.83 & -0.77 \\
\hline & & & 1.09 & 1.07 \\
\hline \multirow[t]{2}{*}{ slaves per capita } & $2.53^{* *}$ & $3.27^{* *}$ & & \\
\hline & 3.45 & 4.73 & & \\
\hline \multirow{2}{*}{ slaves per capita $\times$ House } & $1.90^{*}$ & & & \\
\hline & 1.78 & & & \\
\hline \multirow[t]{2}{*}{ slaves per capita $\times$ Senate } & & -1.57 & & \\
\hline & & 1.28 & & \\
\hline \multirow[t]{2}{*}{ slaves per capita $\times$ Lower South } & & & $3.98^{* *}$ & \\
\hline & & & 1.97 & \\
\hline \multirow[t]{2}{*}{ slaves per capita $\times$ Upper South } & & & 0.40 & \\
\hline & & & 0.16 & \\
\hline \multirow[t]{2}{*}{ slaves per capita $\times$ North } & & & -2.70 & \\
\hline & & & 0.04 & \\
\hline \multirow[t]{2}{*}{ Lower South } & & & & $2.80^{*}$ \\
\hline & & & & 1.87 \\
\hline \multirow[t]{2}{*}{ Upper South } & & & & 1.44 \\
\hline & & & & 1.03 \\
\hline \multirow[t]{2}{*}{ North } & & & & 1.28 \\
\hline & & & & 0.98 \\
\hline \multirow[t]{2}{*}{ dummy vote 132} & $-1.32^{* *}$ & $-1.30^{* *}$ & & \\
\hline & 3.61 & 3.65 & & \\
\hline \multirow[t]{2}{*}{ dummy vote 136} & $-0.97^{* *}$ & $-0.95^{* *}$ & & \\
\hline & 2.60 & 2.58 & & \\
\hline \multirow[t]{2}{*}{ dummy vote 145} & $-1.54^{* *}$ & $-1.53^{* *}$ & & \\
\hline & 4.01 & 4.09 & & \\
\hline
\end{tabular}


Table 3 (Continued)

\begin{tabular}{|c|c|c|c|c|}
\hline & \multicolumn{2}{|c|}{ Apportionment votes } & \multicolumn{2}{|c|}{ Regulation votes } \\
\hline & (I) & (II) & (III) & (IV) \\
\hline \multirow[t]{2}{*}{ dummy vote 147} & -0.53 & -0.54 & & \\
\hline & 1.42 & 1.44 & & \\
\hline \multirow[t]{2}{*}{ dummy vote 253} & 0.43 & 0.46 & & \\
\hline & 1.11 & 1.18 & & \\
\hline \multirow[t]{2}{*}{ dummy vote 999} & & & $-1.33^{* *}$ & $-1.34^{* *}$ \\
\hline & & & 3.32 & 3.27 \\
\hline$N$ & 179 & 179 & 50 & 50 \\
\hline Mean & 0.52 & 0.52 & 0.48 & 0.48 \\
\hline pseudo- $R^{2}$ & 0.25 & 0.25 & 0.24 & $0.24^{\mathrm{a}}$ \\
\hline
\end{tabular}

Notes: Probit estimates appear in the table with absolute $t$-statistics beneath, calculated using robust standard errors

${ }^{\text {a }}$ Calculated by replacing one of the regional dummies with a constant

* $p$-value $\leq 0.10$

** $p$-value $\leq 0.05$

One potential concern with our interpretation of the importance of ambition relates to the House variable. We have used House to measure the personal interest of those who chose to run for the House of Representatives, but delegates who chose to run for Congress simply might have been more concerned with the long term welfare of their state. To distinguish these possibilities, we introduce a new dummy variable Senate, to identify delegates who would run for the Senate during the same time period covered by House. ${ }^{27}$

Because the number of Senate seats assigned to each state would not depend on the method of apportionment, we can distinguish delegates who were interested in the long term welfare of their state from delegates who simply wanted to improve their chances of receiving a seat in Congress by replacing House with Senate in (1). If the estimated effect of the Senate interaction term is the same as that for the House interaction term (positive and significant), then it is likely both are picking up the effect of the importance of the state's interest to the delegate. In other words, they would not be measuring personal interests in the vote. However, if the estimated effect of the Senate interaction term is insignificant, then we can be more confident that the House effect is indeed capturing something specific to those who ran for the House. This would strengthen the argument that House represents the personal interest in the apportionment votes.

We replace House by Senate in the second column of Table 3. This new interaction term is not significant, suggesting that delegates who later sought a Senate seat did not act differently from other delegates. ${ }^{28}$ The other variables in column (II) retain their same signs and significance as in column (I). Thus we conclude that delegates seeking a seat in Congress

\footnotetext{
${ }^{27}$ The Senate variable was coded using the biographies in Garraty and Carnes (1999). Although Senators were elected by state legislatures, they still ran for their seats. For example, William Blount was coded as a 1 because he "unsuccessfully sought election to the U.S. Senate" before heading west in 1790 (Ibid.: 3, 60).

${ }^{28}$ Note the sign of the Senate interaction term is opposite that of the House interaction term. The lack of significance in the former is due to the misspecification of grouping those who ran for House along with
} 
were influenced on the apportionment votes only if they were interested in obtaining a seat in the House. This is consistent with the importance of personal interests, as hypothesized here.

We also ran regressions matching the specifications in columns (I) and (II) using additional vote inferences determined from the spatial methods described in the appendix. As detailed there, the results reinforce our general conclusions.

\subsection{Regulation of the slave trade}

Pooled regression results for specification (2) are presented in column (III) of Table 3. The sign of personalty has now switched compared to the votes on apportionment but it remains insignificant. Delegates of the Methodist and Quaker religions were again less likely to vote pro-slavery, but this time not to a statistically significant degree. The marginal effect of owning slaves is also statistically insignificant. ${ }^{29}$

The only statistically significant variable is the interaction of the number of slaves per capita in a delegate's state with the regional dummy variable for the Lower South. Delegates from the Lower South were more likely to vote pro-slavery on these votes in proportion to the number of slaves per capita in their home state, indicating they were influenced by their state's interests at the margin. The number of slaves per capita in a northern state had no impact on a northern delegate's vote. This is not too surprising given how few slaves existed in the North and the limited variation in slaves per capita among the northern states. ${ }^{30}$ The more interesting result is that the coefficient for slaves per capita interacted with Upper South is not statistically significant. Although the Upper South might find clear advantages to restricting foreign slave imports, this interest apparently did not affect the votes of their delegates in proportion to the slaves per capita in their state. Furthermore, a Wald test suggests the difference between the North and Upper South coefficients is statistically insignificant $(p$-value $=0.97$ ).

It is still possible that regional location affected delegates from the North and Upper South differently. Equation (2) assumes that the variation within the regions depended upon the number of slaves per capita in each state. It does not allow for differences between the regions that are not ordered by the number of slaves. For example, there may be reason to treat all the delegates in the North as a single group rather than trying to differentiate delegates by the number of slaves per capita in their state. The same could also be true for delegates from the Upper South (and Lower South). If, for example, the delegates in the Upper South all equally recognized their state's interest but did not differentiate proportional to the actual number of slaves per capita in their respective states, then a misspecification is introduced by forcing a ranking among the states of the Upper South based on the number of slaves per capita. Of course, this also could be true (in reverse) for the delegates from the Lower South.

To assess this possibility, we report results from a regression replacing the interaction terms with the regional dummies by themselves in the final column of Table $3 .{ }^{31}$ Again,

those who did not run at all as the default category. If both interactions are included in the same regression, the equality of their coefficients can be rejected ( $p$-value $=0.06$ ).

${ }^{29}$ Because Beard classified slave owners as part of the personalty class, including slaveowner separately may not pick up an independent effect. However, the two variables personalty and slaveowner are not even jointly significant $(p=0.43)$ and slaveowner remains insignificant $(p=0.28)$ when personalty is dropped from the regression.

${ }^{30}$ The coefficient remains insignificant even if Delaware is included as part of the North region.

${ }^{31}$ We drop the constant term to avoid perfect collinearity. 
none of the coefficients are significant except for the Lower South. Note, however, that the Lower South dummy, which treats all delegates from the Lower South as identical, is significant at a lower level of confidence than when it is interacted with the number of slaves (see column III). This suggests that the differentiation among Lower South states was not spurious and the original specification may be more appropriate.

In additional regressions, we also included slaves per capita, either as an additional explanatory variable added to those in column (IV) or as a replacement for the regional dummies in column (IV). While always positive, the coefficient on this variable was never statistically significant, suggesting that the marginal effect from slaves in a state had to be separated by region to reveal its importance. We also tested for a simple North/South divide by combining the Upper South and Lower South into a single region. This dummy variable was not significant either by itself or when interacted with the number of slaves per capita.

In total, these results suggest delegates from the Lower South were more actively opposed to regulating the slave trade than delegates from the Upper South (or North). Within the Lower South the effect was most pronounced among delegates from states with more slaves. Our analysis is consistent with a net demand for slave imports in the Lower South. The extended sample described in the appendix produced similar results.

\section{Conclusion}

Jillson and Eubanks (1984) argue that delegates voted consistent with their state interests when state interests were the center of debate and delegates voted differently from their state's interests when philosophical principles were the center of debate. By analyzing issues of slavery, we take Jillson and Eubank's assertion seriously. Issues related to slavery have been widely considered issues of state interest. As such it should be of little surprise to find that delegates voted according to their state interests.

For votes on regulating the slave trade, we found state interests had an effect, as Jillson and Eubank's theory might predict, but the effect was not uniform. Only the delegates from the Lower South were affected by their state's interest.

Conventional wisdom suggests that apportionment issues could affect the interests of the states, but presumably not the direct interests of the delegates themselves. We introduce a personal interest story in the apportionment votes for delegates who ran for the House of Representatives by recognizing that apportionment would affect the number of seats available to each state in the House but not in the Senate. We find that delegates were influenced by this personal interest on the apportionment votes when state interests, personalty, and ideological predispositions were controlled. In other words, delegates who had a personal stake in the apportionment of the legislature may have favored crafting that institution in a way that would advance their own political careers.

In addition, the delegate's religious affiliation appears to have played a role at the margin. Thus apportionment should not be considered solely a matter of state interest, as traditionally viewed. Variation within state delegations mattered and the delegate's personal interests and moral dispositions affected their votes.

Acknowledgements Data collection was supported by the National Science Foundation, SES-0418254. We thank Mercedes Ball, Claudine Smith, and Robi Ragan and for help coding delegate votes and Robert McGuire for the use of some of his data. We further thank Cal Jillson and Charles Stewart for useful comments on an earlier draft as well as suggestions made by participants during a presentation at The American University, School of Public Affairs. Any shortcomings are our own. 


\section{Appendix: Recovering additional observations}

Concerns over missing data led us to explore new methods for uncovering additional delegate votes. In particular, our sample of inferred votes is not a random sample of all delegate positions on the 9 votes presented. The majority of our codes are based on delegates who outwardly expressed their beliefs. Such delegates may have felt stronger about these particular issues or may have been simply more vocal than other delegates. Thus, our results may be more indicative of the factors which affected "expressive" delegates rather than the factors which affected delegates as a whole.

To gain additional data, we added a fourth step which inferred Convention votes based on known votes taken from the Congress of Confederation. This involved the use of single dimensional optimal classification (OC) estimates (Poole 2000) for delegates who served in the Congress of the Confederation anytime between 1777 and 1789 (Lord 1984). ${ }^{32}$ Optimal classification unfolds binary data by first estimating an optimal cutting point for each roll call vote, then optimally classifying voters in the intervals formed by these points. Voters are considered misclassified on a given roll call when their actual vote places them on the wrong side of the cut point. For example, if a congressman is on the nay side of the cut point for roll call $x$ but voted yea, then the vote for that congressman is considered misclassified. Optimal classification involves finding the arrangement of ideal points which minimizes the misclassifications across all roll calls votes. The estimates reflect each congressman's predilection to vote "left" or "right" on issues pertinent to the time.

To see if the policy spaces from the votes at the Congress of the Confederation and the slavery votes at the Constitutional Convention were roughly similar, and could be used to help infer additional votes, we compared the votes inferred in steps 1-3 from the Constitutional Convention to the OC estimates from the 1,594 roll call votes from the Congress of the Confederation. We then determined a separate cut point for each of our nine slavery votes that minimized the number of misclassifications on that roll call. Across the nine Convention votes listed in Table 1 , the overall correct classification rate is roughly $77 \%$, ranging from a low of $73 \%$ for vote 132 to a high of $81 \%$ for vote 136 . This rate is similar to Poole and Rosenthal's (1997) 83\% success rate for all the House votes and $80 \%$ for all the Senate votes (1789-1985), using D-NOMINATE. Our results are all the more striking because we have a small number of voters (between 15 and 24 delegates); hence one misclassified vote has a strong affect on the calculated success rate. Furthermore, unlike Poole and Rosenthal, our classification rates for the Convention are from out of sample predictions. This suggests that the OC space is fairly similar for all issues from the Congress of the Confederation and the slavery issues from the Constitutional Convention.

We use this result to infer additional votes for the delegates not yet coded. For example, none of the attending delegates from New Jersey could be coded in the first three steps on vote 368. Since Jonathan Dayton's (New Jersey) OC estimate lies to the left of the optimal cut point for vote 368 (the side with the yeas), we coded Dayton as a yea because it was more likely that he would have voted with these delegates than not. After we completed this process for all previously uncoded delegates for whom we were able to generate an OC estimate, ${ }^{33}$ we then checked to see

\footnotetext{
${ }^{32}$ There were 1,594 roll call votes recorded during this period at the delegate level. Our OC estimates were created using Elbridge Gerry (Massachusetts) as the restriction.

${ }^{33}$ In rare cases where two or more delegates from the same state were on the same side of the cut line but coding them on the same side was inconsistent with the recorded state vote, we assigned the delegate closest to the cut line the vote inconsistent with that side of the cut line. Our rationale was that ideal points closer to the cut line are more likely to be misclassified than ideal points further from the cut line (Poole 2000).
} 
if the votes of other delegates not yet coded could now be inferred based on the recorded state vote. For example, after Dayton was coded yea on 368, the only remaining two delegates in attendance for New Jersey, David Brearley and William Livingston, were coded nay to keep the majority of the delegation consistent with the state vote.

It is important to note that OC scores could be created only for those delegates who had served in the Congress of the Confederation. The votes of other delegates in attendance were inferred from the first three steps (the votes presented in Table 2) or they were inferred from the state vote during the fourth step; otherwise they remain uncoded for that particular vote. ${ }^{34}$ From this process we were able to code 37 additional apportionment votes and 25 additional regulation votes, representing a $27 \%$ increase in the sample size. ${ }^{35}$

The regressions in Table 3 were re-run using the larger sample. The only substantive changes occurred in the specification represented by column (I). The coefficient on Personalty is now statistically significant at the $10 \%$ level but remained statistically insignificant in all other specifications. In addition, the significance of slaves per capita $\times$ House increased substantially $(t$-stat $=2.32 ; p$-value $=0.02)$. This resulted from an increase in the estimated marginal impact, while the standard error on the estimate remains virtually the same. None of the other coefficients in any of the other specifications were affected to a significant degree. Hence, the extended sample corroborates the results presented in the text.

\section{References}

Allen, W. B. (1988). A new birth of freedom: fulfillment or derailment? In Goldwin, R., Kaufman, A. (Eds.), The Constitution, equality and race (pp. 64-92). Washington: American Enterprise Institute.

Barrow, C. (2000). More than a historian: the political and economic thought of Charles A. Beard. New Brunswick: Transaction Publishers.

Beard, C. ([1913] 2004). An economic interpretation of the Constitution of the United States. New York: Dover Publications.

Bradford, M. E. (1982). A worthy company: brief lives of the framers of the United States Constitution. Marlborough: Plymouth Rock Foundation.

Brown, R. E. (1956). Charles Beard and the Constitution: a critical analysis of "An Economic Interpretation of the Constitution". New York: Norton.

Candler, A. D. (Ed.). (1968). Colonial records of the State of Georgia, 19 reels. Atlanta: Microfilm Division of the Georgia Department of Archives and History.

Delaware, (1797). Laws of the State of Delaware, passed at a session of the General Assembly. Evans \#32030. New Castle: Samuel and John Adams.

Diamond, M. (1981). The founding of the democratic republic. Itasca: Peacock.

DuBois, W. E. B. ([1896] 1969). The suppression of the African slave-trade to the United States of America, 1638-1870. Baton Rouge: Louisiana State University Press.

Dubin, M. J. (1998). United States congressional elections, 1788-1997. Jefferson: McFarland \& Company, Inc.

\footnotetext{
${ }^{34} \mathrm{~A}$ delegate who was misclassified for a given roll call on the basis of an inferred vote from the first three steps was not recoded. In other words, the fourth step was never used to override an already existing code.

${ }^{35}$ We recognize that step 4 may raise questions of its own. Specifically, the method of coding delegates in step 4 is very different than the method in step 2 and uses different information. McGuire (2003) supports his algorithm for determining the codes of additional delegates by noting the mean value of his set of votes is similar to the mean value of the votes already inferred by McDonald (1958). From this McGuire contends both groups came from the same probability distribution and therefore can be combined into one sample. In our sample, the delegates coded from the first three steps have a mean probability of voting yea of 0.52 whereas those coded from step 4 alone had a mean value of 0.57 . This difference is not statistically significant, consistent with McGuire's notion that the two samples come from the same sampling distribution. The additional vote codes (not presented in Table 2) are available upon request.
} 
Essah, P. (1996). A house divided: slavery and emancipation in Delaware, 1638-1865. Charlottesville: University Press of Virginia.

Farrand, M. (Ed.). (1966). The records of the Federal Convention of 1787 (4 Vols.). New Haven: Yale University Press.

Finkelman, P. (2001). Slavery and the founders: race and liberty in the age of Jefferson (2nd ed.). New York: M.E. Sharpe, Inc.

Freehling, W. H. (1972). The founding fathers and slavery. The American Historical Review, 77(1), 81-93.

Garraty, J. A., \& Carnes, M. C. (Eds.). (1999). American national biography. New York: Oxford University Press.

Heckelman, J. C., \& Dougherty, K. L. (2007). An economic interpretation of the Constitutional Convention of 1787 revisited. Journal of Economic History, 67(4), 829-848.

Holcombe, R. G. (2002). From liberty to democracy: the transformation of American government. Ann Arbor: The University of Michigan Press.

Hutson, J. H. (1987). Supplement to Max Farrand's the records of the Federal Convention of 1787. New Haven: Yale University Press.

Jacobson, G. C., \& Kernell, S. (1983). Strategy and choice in Congressional elections (2nd ed.). New Haven: Yale University Press.

Jensen, M. (1964). The making of the American Constitution. Huntington: Robert E. Kreiger Publishing Company.

Jillson, C. (1981). Constitution making: alignment and realignment in the Federal Convention of 1787. American Political Science Review, 75, 598-612.

Jillson, C. (1988). Constitution making: conflict and consensus in the Federal Convention of 1787. New York: Agathon Press.

Jillson, C., \& Anderson, T. (1977). Realignments in the Convention of 1787: the slave trade compromise. Journal of Politics, 39(3), 712-729.

Jillson, C., \& Eubanks, C. L. (1984). The political structure of constitution making: the Federal Convention of 1787. American Journal of Political Science, 28(3), 435-458.

Kaminski, J. P. (Ed.). (1995). A necessary evil? Slavery and the debate over the Constitution. Madison, Wisconsin: Madison House.

Kaminski, J. P., \& Saladino, G. J. (Eds.). (1995). The documentary history of the ratification of the Constitution: commentaries on the Constitution, public and private (Vols. 13-18). Madison: State Historical Society of Wisconsin.

Kernell, S. (1977). Toward understanding 19th century congressional careers: ambition, competition, rotation. American Journal of Political Science, 21, 669-693.

Lord, C. (1984). Roll calls of the Continental congresses and the Congresses of the Confederation, 17771789. ICPSR data set \# 7537.

Maltz, E. M. (1992). Slavery, federalism, and the structure of the Constitution. The American Journal of Legal History, 36(4), 466-498.

McDonald, F. (1958). We the people: the economic origins of the Constitution. Chicago: University of Chicago Press.

McGuire, R. (1988). Constitution making: a rational choice model of the Federal Convention of 1787. American Journal of Political Science, 32(2), 483-522.

McGuire, R. (2003). To form a more perfect union. New York: Oxford University Press.

McGuire, R., \& Ohsfeldt, R. (1984). Economic interests and the American Constitution: a quantitative rehabilitation of Charles A. Beard. The Journal of Economic History, 44(2), 509-519.

McGuire, R., \& Ohsfeldt, R. (1986). An economic model of voting behavior over specific issues at the Constitutional Convention of 1787. The Journal of Economic History, 46(1), 79-111.

McGuire, R., \& Ohsfeldt, R. (1997). Constitutional economics and the American founding. Research in Law and Economics, 18, 143-171.

Miller, J. C. (1991). The wolf by the ears: Thomas Jefferson and slavery. Charlottesville: The University Press of Virginia.

Ohline, H. A. (1971). Republicanism and slavery: origins of the three-fifths clause in the United States Constitution. The William and Mary Quarterly, 28(4), 563-584.

Poole, K. (2000). Non-parametric unfolding of binary choice data. Political Analysis, 8, 211-237.

Poole, K., \& Rosenthal, H. (1997). Congress: a political-economic history of roll call voting. New York: Oxford University Press.

Rakove, J. (1996). Original meanings: politics and ideas in the making of the Constitution. New York: Alfred Knopf.

Robinson, D. L. (1971). Slavery in the structure of American politics, 1765-1820. New York: Harcourt Brace Jovanovich. 
Schlesinger, J. (1966). Ambition and politics: political careers in the United States. Chicago: Rand McNally and Co.

United States. Bureau of the Census. (1975). Historical statistics of the United States, colonial times to 1970. Washington: U.S. Department of Commerce.

Williams, W. H. (1996). Slavery and freedom in Delaware, 1639-1865. Wilmington: Scholarly Resources, Inc. 